\title{
Binomial model of profitability of sales
}

\author{
Rastova Yulia Ivanovna \\ Institute of International Transport Management \\ Admiral Makarov State University of Maritime and Inland \\ Shipping \\ Saint-Petersburg, Russia \\ rastova.yu@unecon.ru
}

\author{
Gorbunova Alla Yurievna \\ International Institute of Economics, Management and \\ Information Systems \\ Altai State University \\ Barnaul, Russia \\ Gorbunova-Alla@mail.ru
}

\author{
Gorbunov Iurii Vadimovich \\ International Institute of Economics, Management and Information Systems \\ Altai State University \\ Barnaul, Russia \\ Barnaul-Gorbunov@mail.ru
}

\begin{abstract}
The article points to a high level of entropy current conditions that determine the need for further development of the methodology and methods of evaluating operating performance. The paper showed it based on the laws of the binomial distribution method for determining the direction of formation of the profitability of sales, in which the process can be developed both in the original plan, and under the influence of risk factors. The article shows a method of structuring the analytical task scheduling using a topological model in the form of a simple directed graph, as well as the possibility of the adjacency matrix in determining the number of pathways (scenarios) on the graph. An example confirms the availability of the above-mentioned method of planning the use of the binomial model for wide application in practice when assessing the cumulative probability and the average value of the negative effect instead of the profitable sales.
\end{abstract}

Keywords-binomial modeling, binomial distribution, sales profitability, operations activity risk

\section{INTRODUCTION}

The economy widely used mathematical models for a long time. They help to clearly set purposes, structure problems, clearly identify existing organizations limitations, calculate future economic performance, when choosing one or another variant of enterprise development, in the end, to find the right management decisions. One such model is the binomial model, which is an important advantage, the ability to simulate the development of the various subsystems of the enterprise, taking into account planned, anticipated events or contingencies. The relevance of using the binomial model is determined by the fact that the modern economy is characterized by a high level of entropy change, which causes high risks. Risk management implies the management of risks not only at the level of strategic management of the organization, but also at the level of its operational activities. The use of the binomial model as a tool for risk management helps to anticipate the risks of operating activities, assess them, if possible to prevent the negative impact of the organization, and if necessary, to mitigate their negative consequences.
The purpose of the research is to explore the possibility of using the binomial model for risk assessment of the operating activities of the organization.

\section{RESEARCH METHODS}

Simulation modeling is used as a method of research, assuming the replacement of the real system under study with its model (logical-mathematical description), which reproduces the real system with sufficient accuracy for the researcher. This method allows experimentation with the model, without resorting to experiments with a real system. Simulation modeling is a kind of mathematical modeling that is used for complex dynamic systems for which analytical models are not developed. The choice of such a method of investigation is predetermined by the peculiarity of the system under study and the purpose of the study.

Activities of companies, accompanied by numerous types of risk, significantly affect its financial results. Risk is defined as the possibility of non-compliance characteristics of the economic state of the object values, anticipated decisionmaking [1].

One of the causes of the risk is the uncertainty in which organizations are forced to stay. Uncertainty is due to incompleteness, inaccuracy of information about the present and future situation of the system and its environment. The reasons for the uncertainty can be an obstacle: the impossibility of foreseeing the development and behavior of the whole variety of elements of the external and internal environment of the organization; and subjective: the lack of proper collection of necessary data by the enterprise.

Virtually all modern organizations operate in the risk situation, the main features of which are as follows [2,3]:

- uncertainties;

- the event is random, meant to realize the possible outcome in practice;

- the existence of the subject of the decision maker;

- the availability of alternative solutions in the subject; 
- the ability to determine the probability of outcomes and expected results;

- the likelihood of loss or the likelihood of additional benefits and others.

In the operations, the following factors are shown:

a) market risk, associated with fluctuations in interest rates, exchange rates, commodity prices and stock prices;

b) event risk - the result of changes in legislation, actions of state bodies, etc ;

c) operational risk (operational risk) as a result of technical errors, intentional and unintentional actions of the personnel, emergency situations.

Let us note that there are such operational risks and related issues as the choice of the development strategy, market positioning, the management level. But since they are not within the purview of risk management, some experts distinguish them as a special business risk [4].

To improve the effectiveness of risk management, international standards are applied: ISO/IEC 31010:2009 «Risk Management - Risk Assessment Techniques», ISO Guide 73:2009 «Risk Management - Vocabulary», ISO 31000:2009 «Risk management - Principles and guidelines, ISO 10014-2008 «Enterprise management. Guidelines for realizing economic benefits in quality management system» $[5,6,7,8]$.

The purpose of these standards is to summarize the international experience of risk management, to find common principles, rules, characteristics, methods, tools that allow managing successfully risks in organizations, engaged in various activities. Standards are based on generalized results of science and practical experience. Creation and their constant improvement contribute to the transition from accidental, intuitive, fragmented risk management to the formation of a scientific knowledge system in this field, to the dissemination of this knowledge around the world.

The main element of the risk management process is a risk assessment that provides an understanding of the hazards, their sources, the possible consequences of an event, the options for maneuvering the organization. It is the risk assessment that allows one to obtain the necessary information for making a decision related to managing it. But to receive such information, it is possible to use only such estimation method which takes into account its feature; otherwise it is possible to obtain unreliable, false data. Recognizing the importance and complexity of applying appropriate risk assessment methods, the developers have created a separate standard: ISO / IEC 31010: 2009 Risk management - Risk assessment techniques. The different qualities of risks predetermined a large number of methods for their evaluation. The purpose of this study is the expediency of analyzing these methods from the position of the field of their application and the use of mathematical models (Table 1).
TABLE 1. Risk assessment methods: scope, use of the mathematical model [7]

\begin{tabular}{|c|c|c|c|}
\hline № & $\begin{array}{l}\text { Name of the } \\
\text { method }\end{array}$ & Application area & $\begin{array}{l}\text { Using } \\
\text { a } \\
\text { mathe- } \\
\text { matical } \\
\text { model }\end{array}$ \\
\hline 1. & Brainstorm & $\begin{array}{l}\text { The method is aimed at encouraging } \\
\text { figurative thinking of participants and is } \\
\text { applicable to all stages of the risk } \\
\text { management process and all stages of the } \\
\text { life cycle of the system. }\end{array}$ & No \\
\hline 2. & $\begin{array}{l}\text { Structured or } \\
\text { partially } \\
\text { structured } \\
\text { interviews }\end{array}$ & $\begin{array}{l}\text { The method is useful in situations } \\
\text { where it is difficult to assemble people } \\
\text { for discussion or when free discussion in } \\
\text { a group is impossible }\end{array}$ & No \\
\hline 3. & $\begin{array}{l}\text { The Delphi } \\
\text { Method }\end{array}$ & $\begin{array}{l}\text { The method is aimed at harmonizing } \\
\text { expert assessments }\end{array}$ & No \\
\hline 4. & Checklists & $\begin{array}{l}\text { The method is used to identify hazards } \\
\text { and risk or to assess the effectiveness of } \\
\text { management tools }\end{array}$ & No \\
\hline 5. & $\begin{array}{l}\text { Preliminary } \\
\text { Hazard Analysis }\end{array}$ & $\begin{array}{l}\text { The method is applicable at the early } \\
\text { stages of project development in the face } \\
\text { of a lack of information on the details } \\
\text { project or work processes. When } \\
\text { analyzing existing systems, the aim is to } \\
\text { rank the risks and risks for subsequent } \\
\text { risk analysis }\end{array}$ & No \\
\hline 6. & $\begin{array}{l}\text { Hazard and } \\
\text { Operability } \\
\text { Study }\end{array}$ & $\begin{array}{l}\text { The scope of the method includes } \\
\text { mechanical and electronic systems, } \\
\text { procedures, software systems, } \\
\text { organizational changes, development and } \\
\text { analysis of legal documents }\end{array}$ & No \\
\hline 7. & $\begin{array}{l}\text { Hazard Analysis } \\
\text { and Critical } \\
\text { Control Points }\end{array}$ & $\begin{array}{l}\text { The method is used in organizations } \\
\text { where production control points are used } \\
\text { for monitoring critical product } \\
\text { parameters }\end{array}$ & No \\
\hline 8. & $\begin{array}{l}\text { Assessment of } \\
\text { toxicological } \\
\text { risk }\end{array}$ & $\begin{array}{l}\text { The method is applicable in various } \\
\text { fields risk management for human health } \\
\text { and the environment }\end{array}$ & No \\
\hline 9. & $\begin{array}{l}\text { Structured what- } \\
\text { if technique }\end{array}$ & $\begin{array}{l}\text { The method is applicable for research of } \\
\text { risks of functioning of chemical, } \\
\text { petrochemical enterprises and other } \\
\text { dangerous systems }\end{array}$ & No \\
\hline 10. & $\begin{array}{l}\text { Scenario } \\
\text { Analysis }\end{array}$ & $\begin{array}{l}\text { The method is useful in making policy } \\
\text { decisions and planning future strategies, } \\
\text { as well as in considering existing } \\
\text { activities. It is used to predict possible } \\
\text { threats and their development in time }\end{array}$ & No \\
\hline 11. & $\begin{array}{l}\text { Business Impact } \\
\text { Analysis }\end{array}$ & $\begin{array}{l}\text { The method is used to determine the } \\
\text { criticality of the organization's processes, } \\
\text { the time of their recovery and the } \\
\text { necessary resources to ensure that the } \\
\text { goals are achieved }\end{array}$ & No \\
\hline 12. & $\begin{array}{ll}\text { Root } & \text { Cause } \\
\text { Analysis } & \end{array}$ & $\begin{array}{l}\text { The method is used to investigate } \\
\text { primary reasons for refusal to work in } \\
\text { various systems: technical, production, } \\
\text { related to labor protection, complex } \\
\text { management systems }\end{array}$ & No \\
\hline 13. & $\begin{array}{l}\text { Failure Mode } \\
\text { Effect Analysis }\end{array}$ & $\begin{array}{l}\text { The method is used to investigate the } \\
\text { mechanisms, consequences and ways to } \\
\text { prevent the failure of projects, products, } \\
\text { processes, systems, software }\end{array}$ & Yes \\
\hline 14. & Fault & The method is used to determine the & Yes \\
\hline
\end{tabular}




\begin{tabular}{|c|c|c|c|}
\hline & Analysis & $\begin{array}{l}\text { qualitative assessment in identifying the } \\
\text { causes of failure and the paths leading to } \\
\text { the final event and the quantification in } \\
\text { the calculation probability of a finite } \\
\text { event if the probabilities of the initial } \\
\text { events are known }\end{array}$ & \\
\hline 15. & $\begin{array}{ll}\text { Event } & \text { Tree } \\
\text { Analysis } & \end{array}$ & $\begin{array}{l}\text { The method is used for modeling, } \\
\text { computing, and ranking (in terms of risk) } \\
\text { different incident scenarios after the } \\
\text { occurrence of the initial event }\end{array}$ & Yes \\
\hline 16. & $\begin{array}{l}\text { Analysis of } \\
\text { causes and } \\
\text { consequences }\end{array}$ & $\begin{array}{l}\text { The method is used to analyze various } \\
\text { options for the operation of the system } \\
\text { after the emergence of critical } \\
\text { developments. Such options can } \\
\text { quantitatively determine the probabilities } \\
\text { of possible consequences of a critical } \\
\text { event }\end{array}$ & Yes \\
\hline 17. & Causal analysis & $\begin{array}{l}\text { The method is used to study all possible } \\
\text { scenarios and the reasons suggested by } \\
\text { the expert group from the position of risk } \\
\text { assessment }\end{array}$ & No \\
\hline 18. & $\begin{array}{l}\text { Layers of } \\
\text { Protection } \\
\text { Analysis }\end{array}$ & $\begin{array}{l}\text { The method can be used as a qualitative } \\
\text { method of investigating the levels of } \\
\text { protection between a hazard or a causal } \\
\text { event and the result }\end{array}$ & No \\
\hline 19. & $\begin{array}{l}\text { Decision tree } \\
\text { analysis }\end{array}$ & $\begin{array}{l}\text { The method is used to manage the risk of } \\
\text { design decisions and in other cases, when } \\
\text { it is necessary to choose the best method } \\
\text { of action in a situation of uncertainty }\end{array}$ & No \\
\hline 20. & $\begin{array}{l}\text { HRA - Human } \\
\text { Reliability } \\
\text { Assessment }\end{array}$ & $\begin{array}{l}\text { The method is used to assess the impact } \\
\text { of human actions, including operator } \\
\text { errors, on work systems. The method can } \\
\text { be used both qualitatively and } \\
\text { quantitatively }\end{array}$ & Yes \\
\hline 21. & $\begin{array}{l}\text { Analysis of } \\
\text { "bow tie" }\end{array}$ & $\begin{array}{l}\text { The method is used to investigate risk } \\
\text { based on demonstrating the range of } \\
\text { possible causes and consequences }\end{array}$ & No \\
\hline 22. & $\begin{array}{l}\text { Reliability } \\
\text { Centered } \\
\text { Maintenance }\end{array}$ & $\begin{array}{l}\text { The method is used to provide efficient } \\
\text { maintenance and is usually applied at the } \\
\text { design and development stage, and then } \\
\text { implemented at the production and } \\
\text { maintenance stage }\end{array}$ & Yes \\
\hline 23. & Sneak Analysis & $\begin{array}{l}\text { The method is used to check the } \\
\text { functionality of the project, analyze } \\
\text { hidden defects. It allows one to identify } \\
\text { problems in both technical and software } \\
\text { tools }\end{array}$ & Yes \\
\hline 24. & Markov analysis & $\begin{array}{l}\text { The method is usually used for the } \\
\text { analysis of maintainable systems, for } \\
\text { calculating their operational readiness }\end{array}$ & Yes \\
\hline 25 . & $\begin{array}{l}\text { Monte Carlo } \\
\text { simulation }\end{array}$ & $\begin{array}{l}\text { The method is used to estimate the } \\
\text { influence of uncertainty in estimating } \\
\text { system parameters in a wide range of } \\
\text { situations }\end{array}$ & Yes \\
\hline 26. & $\begin{array}{l}\text { Bayesian } \\
\text { analysis } \\
\text { Bayesian } \\
\text { networks }\end{array}$ & $\begin{array}{l}\text { The method is applied in any area where } \\
\text { an establishment requires unknown } \\
\text { variables using structural relationships } \\
\text { and data. Bayesian networks can be used } \\
\text { to study causal relationships, deepen } \\
\text { understanding of the problem area and to } \\
\text { predict consequences of interference in } \\
\text { the system }\end{array}$ & Yes \\
\hline 27. & Curves FN & $\begin{array}{l}\text { FN curves can be used to assess risk, } \\
\text { given the likelihood of an event }\end{array}$ & Yes \\
\hline
\end{tabular}

\begin{tabular}{|c|l|l|l|}
\hline 28. & Risk Indices & $\begin{array}{l}\text { The method is used to classify risk types } \\
\text { that require further detailed and possibly } \\
\text { quantitative assessment }\end{array}$ & No \\
\hline 29. & $\begin{array}{l}\text { Matrix of } \\
\text { consequences } \\
\text { and probabilities }\end{array}$ & $\begin{array}{l}\text { The method is used to rank risks, their } \\
\text { sources and measures for risk } \\
\text { management based on the level of risk }\end{array}$ & Yes \\
\hline 30. & $\begin{array}{l}\text { Cost-Benefit } \\
\text { Analysis }\end{array}$ & $\begin{array}{l}\text { The method is used to choose between } \\
\text { various decisions related to risk }\end{array}$ & Yes \\
\hline Analysis & $\begin{array}{l}\text { Multi-Criteria. } \\
\text { Anecision }\end{array}$ & $\begin{array}{l}\text { - comparison of several solutions in the } \\
\text { primary analysis, as a result of which it is } \\
\text { necessary to identify the most preferable } \\
\text { and inappropriate solutions; } \\
\text { - comparison of decision options in the } \\
\text { presence of several, sometimes } \\
\text { conflicting criteria; } \\
\text { - reaching a compromise solution in a } \\
\text { situation where the various parties have } \\
\text { been involved }\end{array}$ & No \\
\hline
\end{tabular}

As can be seen from Table 1, in the solution of wellstructured tasks, the standard recommends using risk assessment methods based on mathematical models. And this is not accidental. The ability to get not only a qualitative but also a quantitative risk assessment, to consider a variety of options for the development of the system, to track the influence of various factors on the forecasted result allow for a better managerial decision.

Let us explore the possibility of using a binomial model to assess the risk of the organization's operational activities.

The binomial model is a tool for the analytical planning a mental and social process, which is reduced to "what is considered the most likely outcome of the situation, given the current actions, policies and forces of the environment, that is, presented as a desirable outcome, which, in turn, requires new actions and policies » [9].

The relevance of the analytical planning is determined by the fact that it involves problem solving under conditions of uncertainty, lack of information about the future behavior of the system and the external environment.

It involves training and the evolution of the system during its development in order to achieve its desired future state. Analytical planning uses the analytic hierarchy method developed by T.Saati.

An analytical scheduling process may take place both in the forward direction and reverse direction. It can be simultaneously organized as analytical planning in the forward and reverse directions [9]:

- direct analytical planning is directed from the current time to the future. This sequence of events is in chronological order. At the same time, considering the current state of the system and the external environment analyzes possible future scenarios;

- analytical planning in the opposite direction starts with defining a desired state of the system (goal-setting) at a given future point in time. Then, the process is considered in a reverse temporal direction, and to evaluate the factors of intermediate states of the system, it is required to achieve the 
desired result. Thus, the reverse planning process influences the direct process, providing motion of the system to the desired state (goal);

- the planning process is carried out simultaneously in both forward and reverse directions, based on the classical theory of planning, which presupposes the existence of two planning purposes. The first goal - a logical and achievable goal; its setting implies that the assumptions and factors, influencing the outcome, will remain substantially unchanged with respect to the present state. The second goal - is a desired one, the achievement of which requires a lot of changes at the inputs. It is necessary not only to implement these changes, but also to make them irreversible, despite the initial behavior of the system.

The main features are the risks in operating activities: integrated nature, objective manifestations, lack of adequate information base and reliable market indicators to assess the level of risk, assessment of subjectivity [10].

As a reliable indicator displays all types of risk, it can be used for gaining profitability. Their analytical and evaluation capabilities can be seen in active use in the practice of financial analysis of the financial leverage effect model (Degree of Financial leverage - DFL), DuPont Model, a twofactor additive-multiplicative model for the profitability of current assets, etc.

However, to assess the risk in the operating activities of the companies, it is not sufficient to determine the sensitivity of financial results to changes in its economic parameters. Many critics argued that the sensitivity analysis is presented in the literature. The most significant disadvantage of it is ignoring the interrelationship of basic variables [11].

This lack is deprivation increasingly used in the practice of risk management binomial 'tree classification and regression model (CART), the model of decision tree and parametric classification models (diskiminanty, logits, probits) [11].

The method, based on the use of the binomial model is often called on behalf of the sponsors by the Cox-RossRubinstein (Cox-Ross-Rubinstein), was proposed in 1979 and described in their work «Option Pricing: A Simplified Approach» [12]. It is very similar to the numerical methods used for solving differential equations. Initially, this approach was used to calculate the value of the US stock options, for which there is no exact analytical solution (Binominal method for option valuation) [11], and was subsequently extended to many more complex derivatives. At present, numerical methods, along with methods of statistical tests (Monte Carlo) are most often used in data reduction models, derivatives, since they allow one to take into account the real conditions of operations with them. But the binomial model can be applied to a wider class of processes such as the management of the investment project parameters [13]. This approach allows us to analyze the process step by step, to determine the factors that affect it, to see the impact of management decisions by the results, to achieve greater administrative flexibility.

The researched model assumes a binomial distribution of the variables - the first of theoretical distributions was found to be associated with the name of the Swiss scientist Bernoulli.
The binomial distribution is a discrete distribution of a random variable taking values $\mathrm{k}=0,1,2, \ldots, \mathrm{n}$. It is formed when $\mathrm{n}$ is random tests, the probability of an event is $p$, and the probability of its appearance is not $q=(1-p)$. For sufficiently large n, let us use the formula Moivre - Laplace.

The binomial model - a discrete distribution model, the application of which requires the implementation of three model conditions [14].

1) analysis of the $n$ consecutive "Bernoulli experiments" when talking about a random event, having two mutually results $(\mathrm{A}$ or $\overline{\mathrm{A}})$. Bernoulli variable is of the form:

$$
\tilde{x}=\left\{\begin{array}{l}
1, \text { when } A \\
0, \text { when } \bar{A}
\end{array}\right\}
$$

2) A result for the probability of occurrence of $p$ is the same in each experiment, usually equal to 0.6 ;

3) Experiments independent of each other; their results do not affect each other.

The law of probability distribution of a random variable, which measures the number of experiments (steps) ending event $\mathrm{A}$, is as follows:

$$
\begin{gathered}
\mathrm{P}\left(\tilde{y}=y_{i}\right)=C_{y i}^{m} \cdot \mathrm{p}^{y_{i}}(1-\mathrm{p})^{\mathrm{n}-y_{i}} \\
\text { when } y_{i}=0,1,2, \ldots \mathrm{n}, \\
C_{y i}^{m}=\frac{y_{i} !}{m !(n-m) !} .
\end{gathered}
$$

Knowing the standard deviation of the average yield of asset $\sigma$, a relative variation of its value can be found:

$$
\begin{aligned}
& 1+\text { relative growth }=u=e^{\sigma \sqrt{h}} \\
& 1+\text { relative reduction }=d=\frac{1}{u},
\end{aligned}
$$

where e - base of natural logarithms, $\mathrm{h}$ - the interval, a part of the year.

The increase in entropy in the economy makes it necessary to use the binomial model for studying the processes now and in the operating activities of the organizations.

To assess the operational risk, using methods of these models, one should take some assumptions.

If one follows strictly the definition of the proposed IFRS operating activities as "the main activity of the company, as well as other activities, excluding financial and investment» [15], the best indicator of the assessment of its profitability would be sales profitability, calculated by EBITDA (earnings before taxes, depreciation and amortization - earnings before interest, taxes, depreciation and amortization).

But in case of modeling (i.e. building a conditional image of the subject being researched, presenting its essential features being important for the research), it is easier to use such index as sales profits. 
Other assumptions for operational risk assessment model based on the sales profitability index are the following:

1) Revenue and profit indicators are determined by the "zero balance" principle. This means they are the result of activities in a current estimable period and cannot be corrected by the remainders of finished products;

2) There is no information about discounts (mark-ups) planned, total sum differences, changes in terms and conditions of agreements/contracts, non-monetary settlements etc.

Sales profitability - the ratio of profit from sales (Pr) to the cost of goods sold (S), i.e., to the sum of revenues from product sales:

$$
R O S=\frac{\operatorname{Pr}}{S}
$$

Changes in sales profitability as a result of effect of factors, determining sales profits and revenues can be presented with an index model:

$$
\begin{gathered}
I_{R O S}=\frac{I_{\mathrm{Pr}}}{I_{S}}, \\
\operatorname{ROS}_{i}=\operatorname{ROS}_{0} \cdot I_{R O S}=R O S_{0} \cdot \frac{I_{\mathrm{Pr}}}{I_{S}}, \\
\operatorname{ROS}_{i}=\operatorname{ROS}_{0} \cdot \frac{100+\Delta \operatorname{Pr}(\%)}{100+\Delta S(\%)},
\end{gathered}
$$

where $I_{R O S}, \quad I_{\mathrm{Pr}}, \quad I_{S}$ are indices, characterizing changes in sales profitability, sales profits and revenues, respectively, as a result of risk factors effect.;

$\Delta \operatorname{Pr}(\%), \Delta S(\%)$ are changes in sales profits and revenues, respectively, as a result of risk factors effect (in percent).

Indices are known as special relational values which, as well as dynamic indicators, spatial comparison or plan execution indicators, give qualitative and quantitative estimation of the results of the phenomenon changes in time, space or compared to initial target. If common relative indices are calculated by an isolated feature, then indices are relative signs of changes in one feature, considered not separately but in a system of features, which is the case under study.

Assessment of risk factors impact on the economic parameters of operations and its financial performance, using the index, taking into account the deviation from the original plan sales $\left(I_{Q}\right)$, prices for products $\left(I_{P}\right)$, prices and rates for variable factors of production $\left(I_{P P}\right)$, fixed costs $\left(I_{F}\right)$, is shown in Table 2. Thus, the profitability of sales as an indicator of operational risk allows us to estimate the impact of factors such as changes in demand, the actions of competitors, changes in prices and tariffs for resources,

\begin{tabular}{|c|c|c|}
\hline \multirow{2}{*}{$\begin{array}{l}\text { Risk factors } \\
\text { effect on } \\
\text { economic } \\
\text { indicators of } \\
\text { operational } \\
\text { activities }\end{array}$} & \multicolumn{2}{|c|}{$\begin{array}{l}\text { Estimation of risk factor effect on financial } \\
\text { performance of operational activities }\end{array}$} \\
\hline & Change in sales profits & Change in revenues \\
\hline $\begin{array}{l}\text { Expected change } \\
\text { in sales volume } \\
\left(I_{Q}\right)\end{array}$ & $\begin{array}{l}\Delta \operatorname{Pr}_{Q}=\operatorname{Pr}_{0} \cdot\left(I_{Q}-1\right) \cdot O L \\
O L-\text { operational leverage }\end{array}$ & $\Delta S_{Q}=S_{0} \cdot\left(I_{Q}-1\right)$ \\
\hline $\begin{array}{l}\text { Expected change } \\
\text { in product } \\
\text { prices }_{\left(I_{P}\right)}\end{array}$ & $\Delta \operatorname{Pr}_{P}=S_{0} \cdot I_{Q} \cdot\left(I_{P}-1\right)$ & $\Delta S_{Q}=S_{0} \cdot I_{Q} \cdot\left(I_{P}-1\right)$ \\
\hline \begin{tabular}{lr}
\multicolumn{3}{l}{ Expected change } \\
in prices and \\
tariffs \\
variable \\
$\operatorname{costs}\left(I_{P P}\right)$
\end{tabular} & $\Delta \operatorname{Pr}_{p p}=C_{0} \cdot I_{Q} \cdot\left(1-\frac{F_{0}}{S_{0}}\right) \cdot\left(1-I_{p p}\right)$ & - \\
\hline $\begin{array}{l}\text { Expected change } \\
\text { in fixed expenses } \\
\text { totals }\left(I_{F}\right)\end{array}$ & $\Delta \operatorname{Pr}_{F}=\operatorname{Pr}_{0} \cdot\left(1-I_{F}\right)$ & - \\
\hline
\end{tabular}
limiting access to them, etc.
TABLE 2. Risk factors effect on economic indicators of operational activities

Total expected change in profits from sales and revenues, compared to the initial target in absolute figures and percentage, is calculated as the result of summing up the estimations of risk factor effects:

$$
\begin{gathered}
\Delta \operatorname{Pr}=\Delta \operatorname{Pr}_{Q}+\Delta \operatorname{Pr}_{P}+\Delta \operatorname{Pr}_{P P}+\Delta \operatorname{Pr}_{F}, \quad \Delta \operatorname{Pr}(\%)=\frac{\Delta \operatorname{Pr}}{\operatorname{Pr}_{0}}, \\
\Delta S=\Delta S_{Q}+\Delta S_{P}, \quad \Delta S(\%)=\frac{\Delta S}{S_{0}} .
\end{gathered}
$$

The binomial model of operational activities risk estimation is based on elementary determination of the direction of setting sales profitability where the process may change under different risk factors. Figure 1 shows the binomial scheme of profitability setting on the base of the considered factor model.

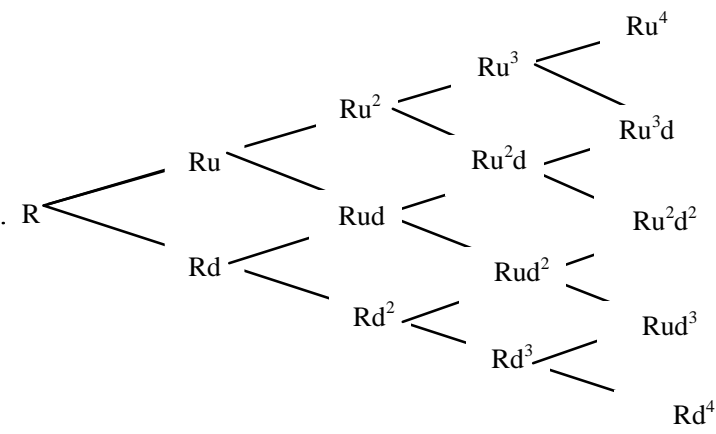

Fig. 1. Binomial scheme establishing the profitability of sales, taking into account risk factors.

Fig. 1 shows a binomial scheme establishing the profitability of sales, taking into account risk factors where: 
$\mathrm{R}$ - current value of sales profitability or the value from the initial target plan;

$\mathrm{Ru}^{\mathrm{i}}$ - the value to which the sales profitability is moving with probability $\mathrm{p}$ if $\mathrm{I}_{\mathrm{i}} \geq 1$

$\mathrm{Rd}^{\mathrm{i}}$ - the value to which the sales profitability is moving with probability $1 p$ if $I_{i}<1$;

I - factor number in the evaluation model of the risk factor effect on economic indicators of operational activities (table $1)$.

Mathematically, the process of the determination of the sales profitability is presented by an adjacency matrix where "1" means the existence of directed connection between the nodes of the directed graph and " 0 " means the lack of it (table 3 ). Each edge of the adjacency matrix $\mathrm{i} \rightarrow \mathrm{j}$ describes, with the given probability, the change in sales profits and revenues compared to initial estimate/target as a result of a corresponding risk factor.

TABLE 3. The description of sales profitability change by adjacency matrix

\begin{tabular}{|c|c|c|c|c|c|c|c|c|c|c|c|c|c|c|c|}
\hline & $\mathrm{R}$ & $\mathrm{Ru}$ & $\mathrm{Rd}$ & $\mathrm{Ru}^{2}$ & $\mathrm{Rud}^{2}$ & $\mathrm{Rd}^{2}$ & $\mathrm{Ru}^{3}$ & $\mathrm{Ru}^{2} \mathrm{~d}$ & $\mathrm{Rud}^{2}$ & $\mathrm{Rd}^{3}$ & $\mathrm{Ru}^{4}$ & $\mathrm{Ru}^{3} \mathrm{~d}$ & $\mathrm{Ru}^{2} \mathrm{~d}^{2}$ & $\mathrm{Rud}^{3}$ & $\mathrm{Rd}^{4}$ \\
\hline $\mathrm{R}$ & 0 & 1 & 1 & 0 & 0 & 0 & 0 & 0 & 0 & 0 & 0 & 0 & 0 & 0 & 0 \\
\hline $\mathrm{Ru}$ & 0 & 0 & 0 & 1 & 1 & 0 & 0 & 0 & 0 & 0 & 0 & 0 & 0 & 0 & 0 \\
\hline $\mathrm{Rd}$ & 0 & 0 & 0 & 0 & 1 & 1 & 0 & 0 & 0 & 0 & 0 & 0 & 0 & 0 & 0 \\
\hline $\mathrm{Ru}^{2}$ & 0 & 0 & 0 & 0 & 0 & 0 & 1 & 1 & 0 & 0 & 0 & 0 & 0 & 0 & 0 \\
\hline $\mathrm{Rud}^{2}$ & 0 & 0 & 0 & 0 & 0 & 0 & 0 & 1 & 1 & 0 & 0 & 0 & 0 & 0 & 0 \\
\hline $\mathrm{Rd}^{2}$ & 0 & 0 & 0 & 0 & 0 & 0 & 0 & 0 & 1 & 1 & 0 & 0 & 0 & 0 & 0 \\
\hline $\mathrm{Ru}^{3}$ & 0 & 0 & 0 & 0 & 0 & 0 & 0 & 0 & 0 & 0 & 1 & 1 & 0 & 0 & 0 \\
\hline $\mathrm{Ru}^{2} \mathrm{~d}$ & 0 & 0 & 0 & 0 & 0 & 0 & 0 & 0 & 0 & 0 & 0 & 0 & 1 & 0 & 0 \\
\hline $\mathrm{Rud}^{2}$ & 0 & 0 & 0 & 0 & 0 & 0 & 0 & 0 & 0 & 0 & 0 & 0 & 1 & 1 & 0 \\
\hline $\mathrm{Rd}^{3}$ & 0 & 0 & 0 & 0 & 0 & 0 & 0 & 0 & 0 & 0 & 0 & 0 & 0 & 1 & 1 \\
\hline $\mathrm{Ru}^{4}$ & 0 & 0 & 0 & 0 & 0 & 0 & 0 & 0 & 0 & 0 & 0 & 0 & 0 & 0 & 0 \\
\hline $\mathrm{Ru}^{3} \mathrm{~d}$ & 0 & 0 & 0 & 0 & 0 & 0 & 0 & 0 & 0 & 0 & 0 & 0 & 0 & 0 & 0 \\
\hline $\mathrm{Ru}^{2} \mathrm{~d}^{2}$ & 0 & 0 & 0 & 0 & 0 & 0 & 0 & 0 & 0 & 0 & 0 & 0 & 0 & 0 & 0 \\
\hline $\mathrm{Rud}^{3}$ & 0 & 0 & 0 & 0 & 0 & 0 & 0 & 0 & 0 & 0 & 0 & 0 & 0 & 0 & 0 \\
\hline $\mathrm{Rd}^{4}$ & 0 & 0 & 0 & 0 & 0 & 0 & 0 & 0 & 0 & 0 & 0 & 0 & 0 & 0 & 0 \\
\hline
\end{tabular}

The adjacency of matrix points with the existence of 16 possible scenarios of the sales profitability formation process (fig. 2).

$\begin{array}{rlllllllll} & \mathrm{R} & & \Delta \mathrm{Q} & & \Delta \mathrm{P} & & \Delta \mathrm{PP} & & \Delta \mathrm{F} \\ 1 & \mathrm{R} & \rightarrow & \mathrm{Ru} & \rightarrow & \mathrm{Ru}^{2} & \rightarrow & \mathrm{Ru}^{3} & \rightarrow & \mathrm{Ru}^{4} \\ 2 & \mathrm{R} & \rightarrow & \mathrm{Ru} & \rightarrow & \mathrm{Ru}^{2} & \rightarrow & \mathrm{Ru}^{3} & \rightarrow & \mathrm{Ru}^{3} \mathrm{~d} \\ 3 & \mathrm{R} & \rightarrow & \mathrm{Ru} & \rightarrow & \mathrm{Ru}^{2} & \rightarrow & \mathrm{Ru}^{2} \mathrm{~d} & \rightarrow & \mathrm{Ru}^{3} \mathrm{~d} \\ 4 & \mathrm{R} & \rightarrow & \mathrm{Ru} & \rightarrow & \mathrm{Ru}^{2} & \rightarrow & \mathrm{Ru}^{2} \mathrm{~d} & \rightarrow & \mathrm{Ru}^{3} \mathrm{~d} \\ 5 & \mathrm{R} & \rightarrow & \mathrm{Ru} & \rightarrow & \mathrm{Rud} & \rightarrow & \mathrm{Ru}^{2} \mathrm{~d} & \rightarrow & \mathrm{Ru}^{3} \mathrm{~d} \\ 6 & \mathrm{R} & \rightarrow & \mathrm{Ru} & \rightarrow & \mathrm{Rud} & \rightarrow & \mathrm{Ru}^{2} \mathrm{~d} & \rightarrow & \mathrm{Ru}^{2} \mathrm{~d}^{2} \\ 7 & \mathrm{R} & \rightarrow & \mathrm{Ru} & \rightarrow & \mathrm{Rud} & \rightarrow & \mathrm{Ru}^{2} \mathrm{~d} & \rightarrow & \mathrm{Ru}^{2} \mathrm{~d}^{2} \\ 8 & \mathrm{R} & \rightarrow & \mathrm{Ru} & \rightarrow & \mathrm{Rud} & \rightarrow & \mathrm{Ru}^{2} \mathrm{~d} & \rightarrow & \mathrm{Ru}^{2} \mathrm{~d}^{2} \\ 9 & \mathrm{R} & \rightarrow & \mathrm{Rd} & \rightarrow & \mathrm{Rud} & \rightarrow & \mathrm{Rud}^{2} & \rightarrow & \mathrm{Ru}^{2} \mathrm{~d}^{2} \\ 10 & \mathrm{R} & \rightarrow & \mathrm{Rd} & \rightarrow & \mathrm{Rud} & \rightarrow & \mathrm{Rud}^{2} & \rightarrow & \mathrm{Ru}^{2} \mathrm{~d}^{2} \\ 11 & \mathrm{R} & \rightarrow & \mathrm{Rd} & \rightarrow & \mathrm{Rud}^{2} & \rightarrow & \mathrm{Rud}^{2} & \rightarrow & \mathrm{Ru}^{2} \mathrm{~d}^{2} \\ 12 & \mathrm{R} & \rightarrow & \mathrm{Rd} & \rightarrow & \mathrm{Rud}^{2} & \rightarrow & \mathrm{Rud}^{2} & \rightarrow & \mathrm{Rud}^{3} \\ 13 & \mathrm{R} & \rightarrow & \mathrm{Rd} & \rightarrow & \mathrm{Rd}^{2} & \rightarrow & \mathrm{Rud}^{2} & \rightarrow & \mathrm{Rud}^{3} \\ 14 & \mathrm{R} & \rightarrow & \mathrm{Rd} & \rightarrow & \mathrm{Rd}^{2} & \rightarrow & \mathrm{Rud}^{2} & \rightarrow & \mathrm{Rud}^{3} \\ 15 & \mathrm{R} & \rightarrow & \mathrm{Rd} & \rightarrow & \mathrm{Rd}^{2} & \rightarrow & \mathrm{Rd}^{3} & \rightarrow & \mathrm{Rud}^{3} \\ 16 & \mathrm{R} & \rightarrow & \mathrm{Rd} & \rightarrow & \mathrm{Rd}^{2} & \rightarrow & \mathrm{Rd}^{3} & \rightarrow & \mathrm{Rd}^{4}\end{array}$

Fig. 2. Scenarios of formation of sales profitability

\section{RESULTS OF THE STUDY.}

The application of the model considered can be illustrated by an example. The input data for calculation are presented in table 4 . In the calculation, a moderately pessimistic estimation of possible development of events is used: the probability of events in accordance with the initial calculation - 0.6 , and at the risk of manifestation of the reasons - 0.4 respectively.

TABLE 4. Input data for determining sales profitability with the allowance for risk factors

\begin{tabular}{|l|c|c|c|}
\hline \multicolumn{1}{|c|}{ Indicators } & Symbols & Input data & $\begin{array}{c}\text { Indices of change } \\
\text { compared with } \\
\text { the initial plan }\end{array}$ \\
\hline Sales volume, units & $\mathrm{Q}$ & 1000 & 0,8 \\
\hline Price, roubles & $\mathrm{P}$ & 225 & 0,9 \\
\hline $\begin{array}{l}\text { Variable costs for a } \\
\text { production unit, roubles }\end{array}$ & $\mathrm{V}$ & 125 & 1,05 \\
\hline $\begin{array}{l}\text { Fixed costs estimate, } \\
\text { roubles }\end{array}$ & $\mathrm{F}$ & 60000 & 1,1 \\
\hline
\end{tabular}

According to the initial target, sales profitability could be $17.8 \%$. Permissible probable distribution of operational activities indicators with an allowance for risk factors is shown in table 5 .

TABLE 5. Calculation of sales profitability using a binomial model for estimating the risk of operational activities

\begin{tabular}{|c|c|c|c|c|}
\hline Scenario & $\mathrm{p}$ & $\Delta \operatorname{Pr}(\%)$ & $\Delta \mathrm{S}(\%)$ & $\begin{array}{c}\mathrm{ROS}, \\
\%\end{array}$ \\
\hline 1 & 0.1296 & 0.0 & 0.0 & 17.8 \\
\hline 2 & 0.0864 & -15.0 & 0.0 & 15.1 \\
\hline 3 & 0.0864 & -15.6 & 0.0 & 15.0 \\
\hline 4 & 0.0576 & -30.6 & 0.0 & 12.3 \\
\hline 5 & 0.0864 & -56.3 & -10.0 & 8.6 \\
\hline 6 & 0.0576 & -71.3 & -10.0 & 5.7 \\
\hline 7 & 0.0576 & -71.9 & -10.0 & 5.6 \\
\hline 8 & 0.0384 & -86.9 & -10.0 & 2.6 \\
\hline 9 & 0.0864 & -50.0 & -20.0 & 11.1 \\
\hline 10 & 0.0576 & -65.0 & -20.0 & 7.8 \\
\hline 11 & 0.0576 & -62.5 & -20.0 & 8.3 \\
\hline 12 & 0.0384 & -77.5 & -20.0 & 5.0 \\
\hline 13 & 0.0576 & -95.0 & -28.0 & 1.2 \\
\hline 14 & 0.0384 & -110.0 & -28.0 & -2.5 \\
\hline 15 & 0.0384 & -107.5 & -28.0 & -1.9 \\
\hline 16 & 0.0256 & -122.5 & -28.0 & -5.6 \\
\hline
\end{tabular}

The value of sales profitability, taking into account the expected earnings deviations from sales and revenue, can vary from $17.8 \%$ to $-5.6 \%$. In the three scenarios with a total probability of 0.1024 , return on sales would be negative. The expectation of profit margin $-8.95 \%$.

\section{CONCLUSION}

Operating activities of each organization, working in conditions of uncertainty, are at greater risk. The authors propose evaluating the operations and information risk management of decision-making to use the factor model of profitability of sales, which is a form of the binomial model. Using this model takes into account both the original planning conditions and so unexpected emerging factors that create 
additional risks of conducting operations. Application of this method of planning contributes to the profitability of sales, in the first place; the improvement of the operational management of the organization, in particular, increases the financial flexibility of the company and production. Second the improvement of strategic management implies selection of the most important goals and identifying ways of achieving them.

Thus, the purpose of the study has been achieved: ability to use the binomial model for risk assessment of the operating activities of the organization has been proven.

The proposed methodology of analysis and risk assessment of operations using the indicator of profitability of sales, in the authors' opinion, allows one to obtain reliable results and is quite affordable for a wide application of it in practice to justify management decisions.

\section{References}

[1] S.O. Hansson, "Risk", The Stanford Encyclopedia of Philosophy (Winter 2012 Edition).

[2] V. Seliva, The theory of real options and management of financial risks of development projects. Moscow: Publishing house of Financial University under the Government of the Russian Federation, 2014, 178 p.

[3] A. Kozlovskiy, Y. Kulik, "Classification of Investment Risks", Scientific and Technical Statements of St. Petersburg State Polytechnical University. Economic Sciences, vol. 3 (173), Publishing house of Peter the Great St.Petersburg Polytechnic University, pp. 158-163, 2013. ISSN: 2304-9774.
[4] Basel II: International Convergence of Capital Measurement and Capital Standards: A Revised Framework - Comprehensive Version. Bank for International Settlements, Basel, Switzerland, 2006, ISBN print: 929131-720-9.

[5] ISO/IEC 31010:2009, «Risk Management - Risk Assessment Techniques».

[6] ISO Guide 73:2009 «Risk Management - Vocabulary».

[7] ISO 31000:2009 «Risk management - Principles and guidelines».

[8] ISO 10014-2008 «Enterprise management. Guidelines for realizing economic benefits in quality management system».

[9] T.L. Saaty, K.P. Kearns, Analytical Planning. The Organization of Systems. Pergamon Press, 1985

[10] I.V. Volikova, Yu.I. Rastova, "Investment Risk Policy modern organization", News of Altai State University, Barnaul, vol. 2-2, pp. 254-257, 2010.

[11] R. Brealey, S. Myers, F. Allen, Principles of Corporate Finance, 11th Edition. - McGraw-Hill/Irwin, 2014, 1005 p.

[12] J. Cox, S. Ross, M. Rubinstein, "Option Pricing: A Simplified Approach “, Journal of Financial Economics, Vol. 7, Issue 3, pp. 229-263, 1979. DOI: 10.1016/0304-405X(79)90015-1.

[13] Yu. I. Rastova, "Analytical Planning of the Parameters of the Investment Project with Use of Binomial Modeling Techniques", Herald of Omsk University, Series «Economics», vol. 4, Publisher of Dostoevsky Omsk State University, pp. 37-52, 2015.

[14] L. Kruschwitz, Finanzierung und investition. Munchen, Wien, R. Oldenbourg Verlag, 563 p., 1999.

[15] IAS 7. Cash Flow Statements. 2015. http://base.consultant.ru/cons/cgi/online.cgi?req=doc;base=LAW;n=193 533 ;fld $=134$; from $=148049$ ;rnd=189271.9813671173901259;;ts=018927109294 14365348682. 